\title{
A New Cost-Benefit and Rate of Return Analysis for the Perry Preschool Program: A Summary
}

James Heckman

Seong Moon

Rodrigo Pinto

Peter A. Savelyev

William \& Mary, pasavelyev@wm.edu

Follow this and additional works at: https://scholarworks.wm.edu/asbookchapters

Part of the Behavioral Economics Commons, and the Health Economics Commons

\section{Recommended Citation}

Heckman, J., Moon, S., Pinto, R., \& Savelyev, P. A. (2010). A New Cost-Benefit and Rate of Return Analysis for the Perry Preschool Program: A Summary. Arthur J. Reynolds, Arthur J. Rolnick, Michelle M. Englund, Judy A. Temple (Ed.), Childhood Programs and Practices in the First Decade of Life: A Human Capital Integration (pp. 366-380). New York: Cambridge University Press. https://scholarworks.wm.edu/ asbookchapters/103 


\title{
A New Cost-Benefit and Rate of Return Analysis for the Perry Preschool Program: A Summary
}

\author{
JAMES J. HECKMAN, SEONG HYEOK MOON, RODRIGO PINTO, \\ PETER SAVELYEV, AND ADAM YAVITZ
}

\section{INTRODUCTION}

The Perry Preschool Program was an early childhood education program conducted at the Perry Elementary School in Ypsilanti, Michigan, during the early 1960s. The evidence from it is widely cited to support the economic argument for investing in early childhood programs.

Only disadvantaged children living in adverse circumstances who had low IQ scores and a low index of family socioeconomic status were eligible to participate in the Perry program. Actual participation was determined by a toss of a coin. Beginning at age 3 and lasting 2 years, treatment consisted of a 2.5hour preschool program on weekdays during the school year, supplemented by weekly home visits by teachers. The curriculum was based on supporting children's cognitive and socio-emotional development through active learning in which both teachers and children had major roles in shaping children's learning. Children were encouraged to plan, carry out, and reflect on their own activities through a plan-do-review process. Follow-up interviews were conducted when participants were approximately 15, 19, 27, and 40 years old. At these interviews, participants provided detailed information about their life-cycle trajectories including schooling, economic activity, marital life, child rearing, and incarceration. In addition, Perry researchers collected administrative data in the form of school records, police and court records, and records on welfare participation.

As the oldest and most cited early childhood intervention, the Perry study serves as a flagship for policy makers advocating public support for early childhood programs. Schweinhart et al. (2005) and Heckman, Moon, Pinto, Savelyev, and Yavitz (2010b) describe the program and its outcomes in detail and report substantial short-term and long-term treatment effects. They report crime reduction as a major benefit.

However, critics of the Perry program point to the small sample size of the study, the lack of a substantial long-term effect of the program on IQ, and 
the absence of statistical significance for many estimated treatment effects. Anderson (2008) claims that the program does not work for boys, although he examines only a subset of its outcomes using arbitrarily constructed indices of diverse outcomes, and he does not perform a cost-benefit analysis overall or by gender. ${ }^{2}$ The existing cost-benefit analyses of the program do little to assuage these concerns, presenting estimates of rates of returns without standard errors, leaving readers uncertain as to whether the estimates are statistically significantly different from zero. ${ }^{3}$ In response, Heckman, Moon, Pinto, Savelyev, and Yavitz (2010a) present the first rigorous cost-benefit study of the Perry program that addresses four major challenges: (a) the compromise inherent in the randomization protocol (see Heckman et al. 2010b); (b) the lack of program data past age 40 and the need to extrapolate out-of-sample to obtain earnings profiles past that age to estimate lifetime impacts of the program; (c) missing data for participants before age 40; and (d) the difficulty in assigning reliable values to nonmarket outcomes, such as crime. The last point is especially relevant for any analysis of the Perry program because crime reduction is touted as one of its major benefits. This chapter summarizes the main findings from our study. For more detailed discussion of the results summarized here, see Heckman et al. (2010a).

Table 17.1 presents the range of estimates from our preferred methodology, defended in Heckman et al. (2010a). It reports separate rates of return for benefits accruing to individuals versus those that accrue to society at large. Our estimate of the overall social rate of return to the Perry program is in the range of $7 \%$ to $10 \%$. We report a range of estimates because of uncertainty about some components of benefits and costs that cannot be quantified by standard errors alone. These estimates are above the historical return to equity, ${ }^{4}$ but generally below estimates reported in previous studies.

\section{PROGRAM COSTS AND BENEFITS}

We confine our evaluation to the costs and benefits of education, earnings, criminal behavior, tax payments, and participation in public welfare programs. There are no reliable data on health outcomes, marital and parental outcomes, the quality of social life, and the like. Our estimated rate of return likely understates the true rate of return, although we have no direct evidence on this issue.

1 See Herrnstein and Murray (1994, pp. 404-405) and Hanushek and Lindseth (2009).

2 See Heckman et al. (2010b), who use small sample permutation tests and multiple hypotheses-testing methods to establish that there are strong treatment effects for boys and girls, although their life-cycle realizations differ across groups.

3 See Rolnick and Grunewald (2003) and Belfield et al. (2006).

4 The post-World War II stock-market rate of return on equity is $5.8 \%$ (see DeLong and Magin, 2009). 


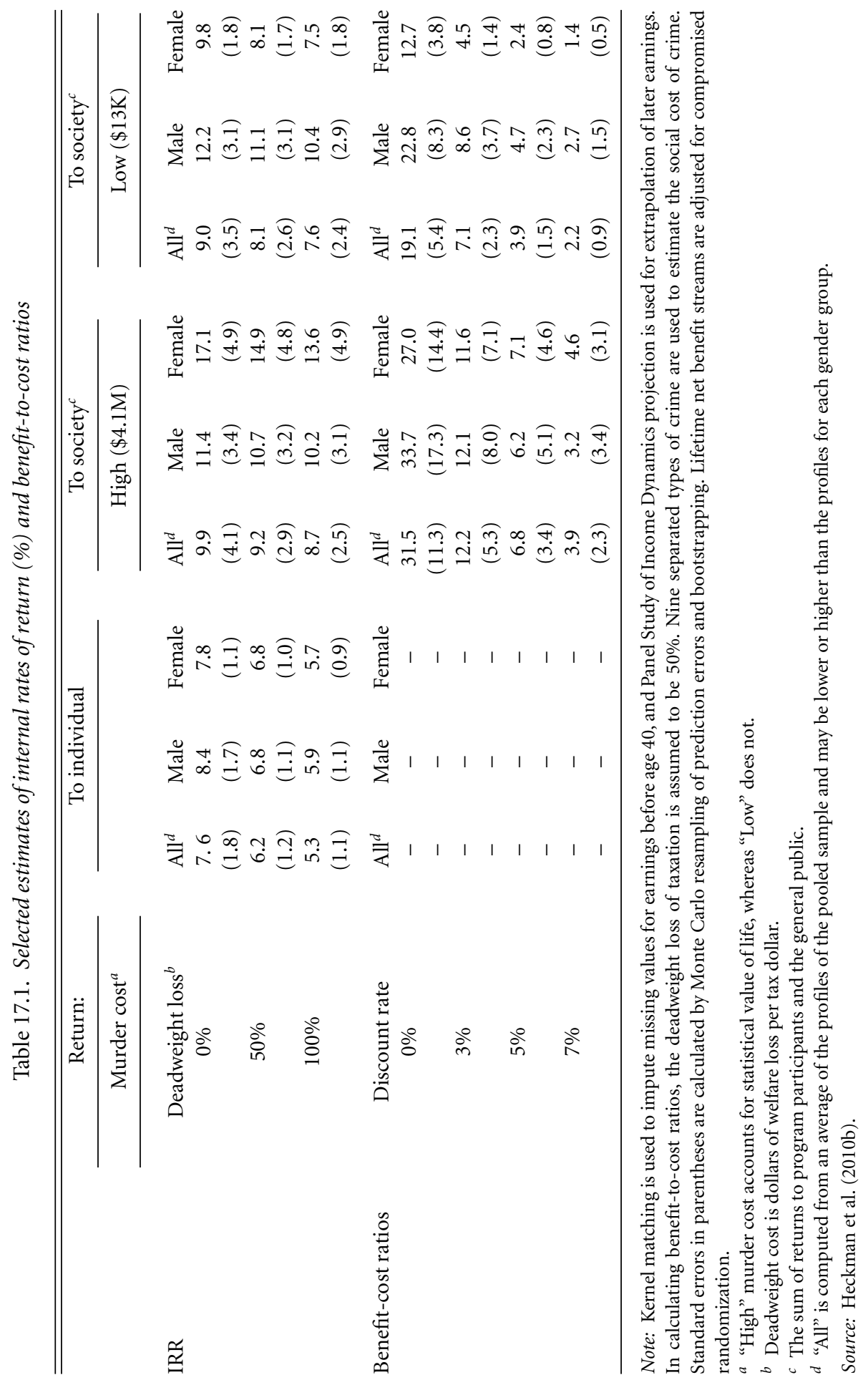




\section{Initial Program Cost}

We use the estimates of initial program costs presented in Barnett (1996), which include both operating costs (teacher salaries and administrative costs) and capital costs (classrooms and facilities). In undiscounted year-2006 dollars, the cost of the program per child is $\$ 17,759$.

\section{Education}

Perry promoted educational attainment through two avenues: total years of education attained and rates of progression to a given level of education. We estimate tuition and other pecuniary education costs paid by individuals, as well as additional social costs incurred by society to educate them. The amount of educational expenditure that the general public spends will be larger if participants attain more schooling or if they progress through school less efficiently. We estimate the cost of regular K-12 education, GED, special education, higher education, and vocational training. Table 17.2 summarizes the components of our estimated educational costs. Treated females received less special education, progressed more quickly through grades, earned higher GPAs, and attained higher levels of education than their control-group counterparts. (For males, however, the impact of the program on schooling attainment was weak at best.) As a result, society spent comparable amounts of resources on individuals during their $\mathrm{K}-12$ years regardless of their treatment experience, albeit for different reasons.

\section{Employment and Earnings}

To construct lifetime earnings profiles, Heckman et al. (2010a) solve two practical problems. First, in the original survey, job histories were determined retrospectively only for a fixed number of previous job spells. Thus, data on missing spells had to be imputed by econometric techniques. Second, because the Perry data were not collected after the age- 40 interview, it is necessary to predict earnings profiles beyond this age or else to estimate rates of return through age 40 . To impute missing values for ages before the age- 40 interview, we use four different imputation procedures:

1. We use a simple piecewise linear interpolation, based on weighted averages of the nearest observed data points around missing values.

2. We impute missing values using estimated Mincerian earnings functions fit on the 1979 National Longitudinal Survey of Youth (NLSY79) "lowability" African American subsample born in the same years as the Perry subjects. ${ }^{5}$

5 This "low-ability" subsample is selected by initial background characteristics that mimic the eligibility rules used in the Perry program. NLSY79 is a nationally representative longitudinal
$<i>$ Childhood ProgramS and Practices in the First Decade of Life. A Human Capital Integration<i $>$, edited by Arthur J. 


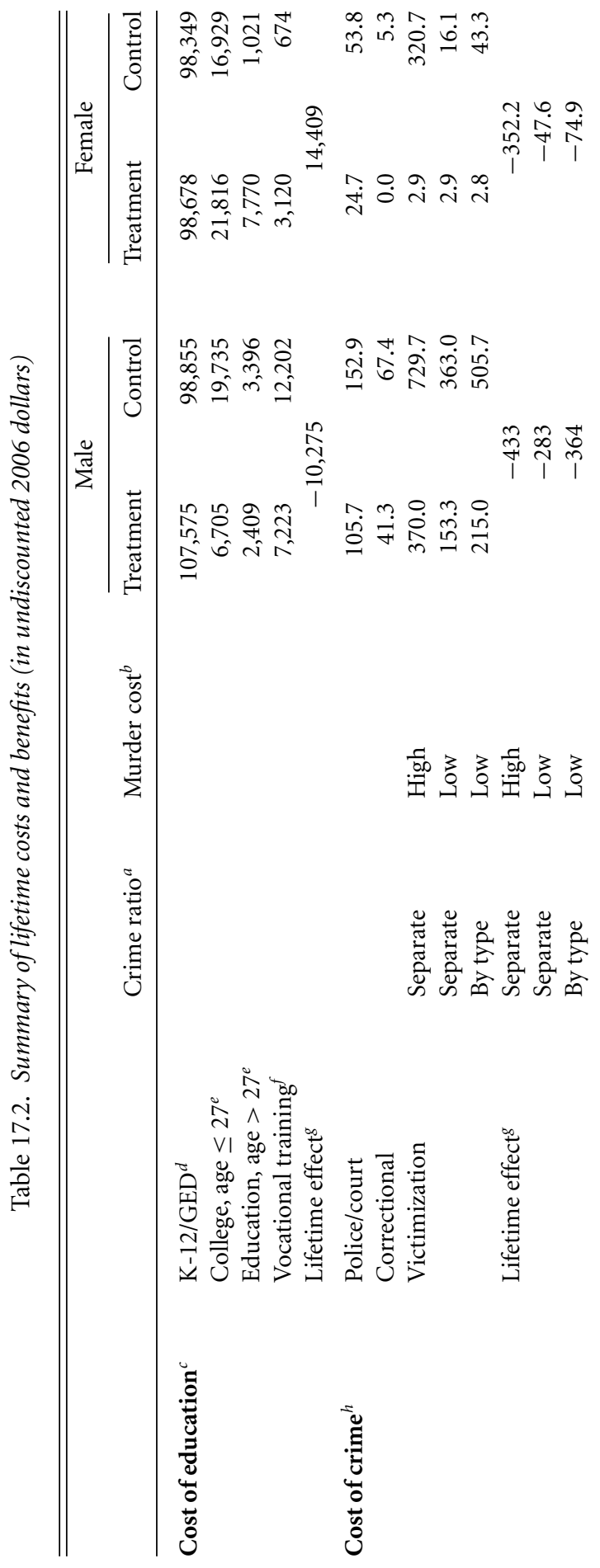

$<i>$ Childhood Programs and Practices in the First Decade of Life : A Hußra (0)Capital Integration</i>, edited by Arthur J.

Reynolds, et al., Cambridge University Press, 2010. ProQuest Ebook Central, http://ebookcentral.proquest.com/lib/cwm/detail.action?doclD=5644 Created from cwm on 2019-09-30 08:54:46. 


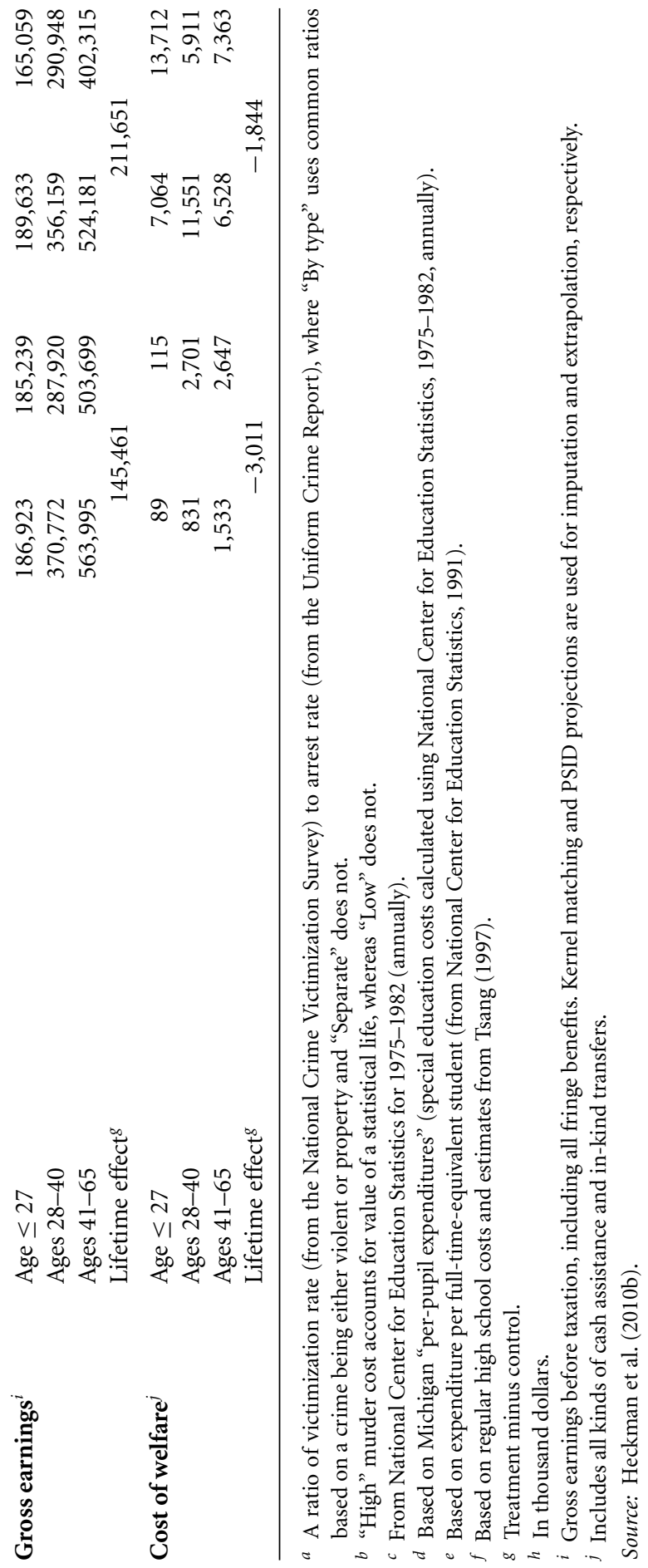

$<i>C$ Childhood Programs and Practices in the First Decade of Life : A Hußn $\bar{A}$ r Capital Integration</i>, edited by Arthur J.

Reynolds, et al., Cambridge University Press, 2010. ProQuest Ebook Central, http://ebookcentral.proquest.com/lib/cwm/detail.action?doclD=5644 Created from cwm on 2019-09-30 08:54:46. 
3. We use a kernel-matching method that sorts each Perry subject to similar observations in the NLSY79 sample. We match each Perry subject to all observations in the NLSY79 comparison-group sample, but with different weights that depend on the estimated kernel function.

4. We estimate dynamic earnings functions using the method of Hause (1980).

Given the absence of earnings data after age 40, we employ three extrapolation schemes to extend sample earnings profiles to later ages:

1. We use March 2002 Current Population Survey (CPS) data to obtain earnings growth rates up to age 65 . Because it was not possible to extract "low-ability" subsamples from the CPS that are comparable to the Perry control group, we use CPS age-by-age growth rates (rather than levels of earnings) of 3-year moving averages of earnings by gender and educational attainment.

2. We use a "low-ability" subsample of the Panel Study of Income Dynamics (PSID). We first estimate a random-effects model of earnings on the PSID and then use the fitted model to extrapolate earnings in Perry data after age 40 .

3. We also use individual parameters from an estimated version of the model of Hause (1980).

All methods are conservative in that they impose the same earnings structure on the missing data for treatment and controls. ${ }^{6}$ The earnings include all types of fringe benefits listed in Employer Costs for Employee Compensation, a Bureau of Labor Statistics compensation measure. Table 17.2 presents the estimated gross earnings for a selected combination of imputation and extrapolation methods. See Heckman et al. (2010a) for further details.

\section{Criminal Activity}

Crime reduction is a major benefit of the Perry program. ${ }^{7}$ Valuing the effect of this reduction in terms of costs and benefits is not a trivial issue, given the difficulty of assigning reliable monetary values to nonmarket outcomes. Heckman et al. (2010a) improve on previous studies (e.g., Belfield, Nores, Barnett, \& Schweinhart, 2006) by exploring the impact of using a variety of assumptions to obtain the benefit-cost ratios. For each subject, the Perry data provide a full record of arrests, convictions, charges, and incarcerations

survey, whose respondents are almost the same age (birth years 1956-1964) as the Perry sample (birth years 1957-1962). See Heckman et al. (2010a).

6 All profiles used here incorporate survival rates by age, gender, and education, which are obtained from National Vital Statistics Reports (National Center for Health Statistics, 2004).

7 See, for example, Schweinhart et al. (2005) and Heckman et al. (2010b). 
for most of adolescence and adulthood obtained from administrative data sources. ${ }^{8}$

The total social cost of a crime can be calculated as a product of the social cost per unit of crime and the incidence. The empirical challenges of evaluating the cost of crime are twofold: obtaining a complete lifetime profile of criminal activities for each person and assigning relevant monetary value to each type of criminal activity. It is difficult to obtain complete lifetime crime profiles because we do not directly observe each person's participation in criminal activity. Instead, we only observe arrests from police records. To fill the gap between the actual level of crime and arrests, we combine three data sets: (a) the Uniform Crime Report (UCR), which provides arrest rates by gender, race, and age for each year; (b) the National Crime Victimization Survey (NCVS), which is a nationally representative household-level data set on criminal victimization that provides information on unreported crime levels across the United States; and (c) Perry crime records. From the first two data sources, we can compute the ratio of the true incidence level to the total arrests for each type of crime; by multiplying this ratio by the number of arrests of each subject in the Perry data and summing them over crime types and subjects, we compute the true incidence level. To assign relevant monetary values to criminal activities, we compute the unit cost of each type of crime, which is broken down into two components - victimization costs and criminal justice system costs - using estimates in existing literature as well as various data sources such as Expenditure and Employment data for the Criminal Justice System (CJEE). ${ }^{9}$ Different types of crime are associated with different unit costs. Table 17.2 summarizes our estimated social costs of crime.

Our approach differs from that used by Belfield et al. (2006) in several respects. First, in estimating victimization-to-arrest ratios, police and court costs, and correctional costs, we use local data rather than national figures. Second, we use two different values of the victim cost of murder: an estimate of "the statistical value of life" ( $\$ 4.1$ million) and an estimate of assault victim cost $(\$ 13,000)$. We report separate rates of return for each estimate. Third, we assume that there are no victim costs associated with "driving misdemeanors" and "drug-related crimes." Whereas previous studies have assigned nontrivial victim costs to these types of crimes, we consider them to be "victimless." However, because such crimes could be the proximal causes of victimizations, we separately account for any crimes with victims that result from initially victimless crimes. Our approach results in a substantial decrease in crime cost compared to the cost of crime used in previous studies because victimless crimes account for more than $30 \%$ of all crime reported in the Perry study. 


\section{Tax Payments and Welfare Dependence}

Taxes are transfers from the taxpayer to the rest of society and represent benefits to recipients that reduce the welfare of the taxed unless services are received in return. Conversely, higher earnings translate into higher absolute amounts of income-tax payments (and consumption-tax payments) that are beneficial to the general public, excluding program participants. Although there have been changes in U.S. income tax rates over the period covered by this evaluation, in our work, we simplify the calculation by applying a $15 \%$ individual tax rate and $7.5 \%$ FICA tax rate to each subject's taxable earnings for each year. Belfield et al. (2006) used the employer's share of FICA tax in addition to these two components in computing the benefit to the general public, but we do not because a recent consensus among economists is that "the employer's share of payroll taxes is passed on to employees in the form of lower wages than would otherwise be paid"10 (Congressional Budget Office, 2007, p. 3 ).

Differentials in the use of welfare are another important source of benefits from the Perry program. We distinguish transfers, which benefit one group in the society at the expense of another, from the costs associated with making such transfers. Only the latter should be counted in computing gains to society as a whole. Because of data limitations, we adopt the following method to estimate full lifetime profiles of welfare receipt. ${ }^{11}$ First, we use the NLSY79 and PSID comparison samples to impute the amount received from various cash assistance and food-stamp programs in a fashion similar to our method for earnings imputation and extrapolation. Second, to account for in-kind transfers, we employ the Survey of Income and Program Participation data to calculate the probability of participating in specific in-kind transfer programs for a "less-educated" Black population and then convert it to monetary values using the estimates of Moffitt (2003) for real public expenditures on welfare programs. Table 17.2 summarizes our estimated profiles of welfare use. For society, each dollar of welfare involves administrative costs. Based on Michigan state data, Belfield et al. (2006) estimated a cost to society of 38 cents for every dollar of welfare disbursed. We use this estimate to calculate the cost of welfare programs to society.

\section{INTERNAL RATES OF RETURN AND BENEFIT-TO-COST RATIOS}

We calculate internal rates of return and benefit-to-cost ratios for the Perry program under various assumptions and estimation methods. We compute the associated standard errors in three steps. In the first step, we use the bootstrap

10 The Perry data do not provide enough information about receipt of various in-kind transfer programs. Even for cash-assistance programs, we do not have complete lifetime profiles of cash transfers for each individual.

11

See Heckman et al. (2010a) for further discussion. 
to simultaneously draw samples from Perry and other nonexperimental comparison data sets (e.g., the NLSY79 and the PSID). For each replication, we reestimate all parameters used to impute missing value and recompute all components used in the construction of lifetime profiles. In this process, all components of earnings whose computations do not depend on the comparison group data are also recomputed (e.g., social cost of crime, educational expenditure) because the replicated sample consists of randomly drawn Perry participants. In the second step, we adjust all imputed values for prediction errors by plugging in an error term that is randomly drawn from comparisongroup data in a Monte Carlo resampling procedure. Combining these two steps allows us to account for both estimation errors and prediction errors. Finally, we compute point estimates of internal rates of return (IRRs) and benefit-to-cost ratios for each replication to obtain bootstrapped standard errors.

Tables 17.1 and 17.3 show estimated IRRs and associated standard errors computed using various methods for estimating earnings profiles and crime costs under various assumptions about the deadweight cost of taxation. We first set the victim cost associated with a murder at $\$ 4.1$ million, which includes the statistical value of life (column labeled "High"), and then at $\$ 13,000$, which is set to the victim cost of assault, to avoid the problem that a single murder might dominate the evaluation (columns labeled "Low"). To gauge the sensitivity of estimated returns to the way crimes are categorized, we compare results from two aggregation schemes: "Separated" and "Property Versus Violent Crimes." 12 The estimates reported in these tables account for the deadweight costs of taxation: dollars of welfare loss per tax dollar. For comparison purposes, we select the kernel-matching imputation and PSID projection of missing earnings in Table 17.1. Our estimates are robust to the choice of alternative extrapolation/interpolation procedures. Because, as documented by Heckman et al. (2010b), the randomization protocol implemented in the Perry program is somewhat problematic, we adjust all lifetime cost and benefit streams for the compromise in randomization by conditioning them on relevant preprogram variables. This is a form of matching.

The estimated rates of return reported in Table 17.3 are comparable for all of the imputation and extrapolation schemes. Alternative assumptions about the victim cost of murder affect the estimated rates of return in a counterintuitive fashion. Assigning a high number to the value of a life lowers the estimated rate of return because the one murder committed by a treatmentgroup male occurs earlier than the two committed by males in the control group. The rates of return are not very sensitive to the crime-categorization method, as shown by comparison of the last two sets of columns. Adjusting for deadweight losses of taxes lowers the rate of return to the program. Our 


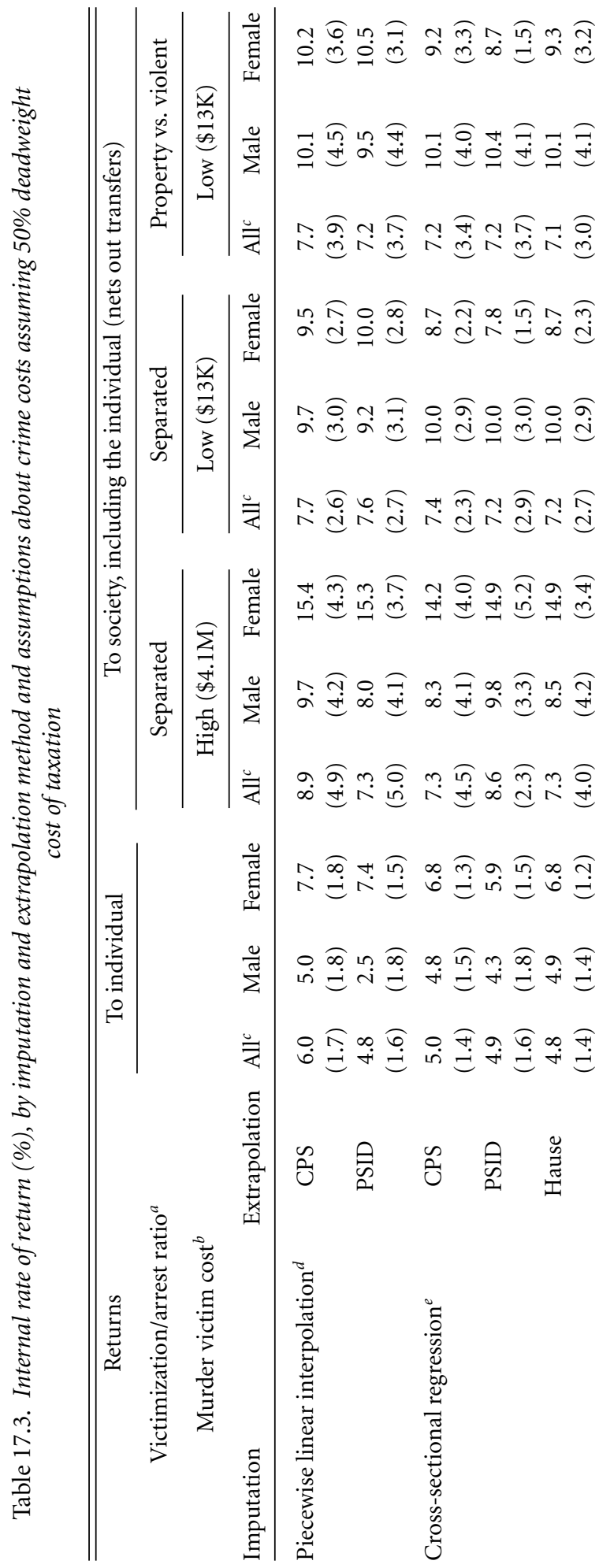




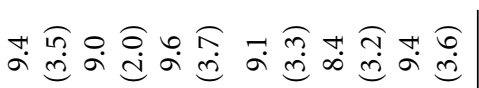

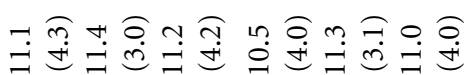

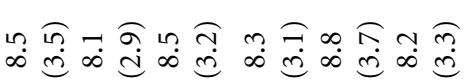

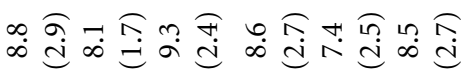

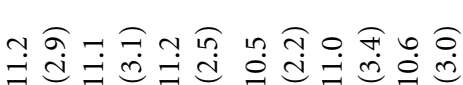

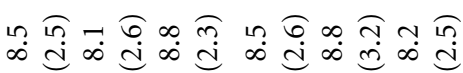

$$
\begin{aligned}
& \text { กิด } \\
& \text { घ }
\end{aligned}
$$

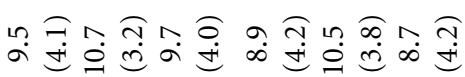

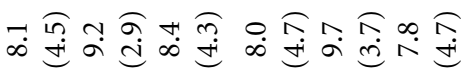

$$
\begin{aligned}
& \text { }
\end{aligned}
$$

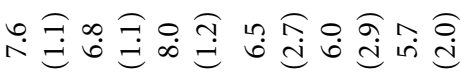

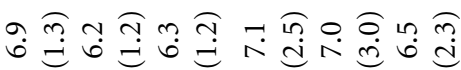

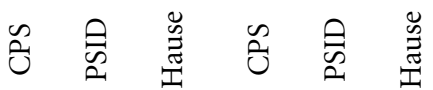

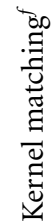

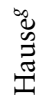

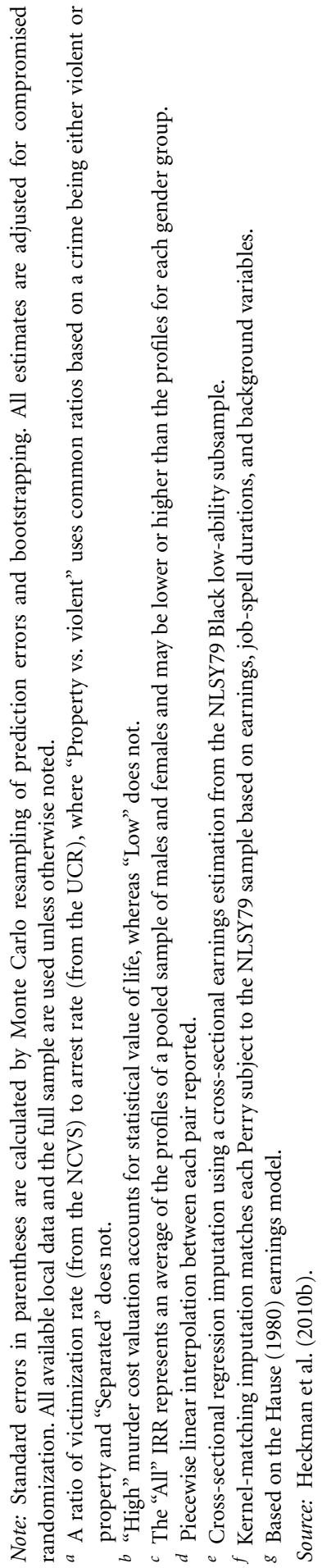


Table 17.4. Decomposition of benefit-to-cost ratios: Crime versus other outcomes

\begin{tabular}{|c|c|c|c|c|c|c|c|c|c|}
\hline \multirow{2}{*}{$\begin{array}{l}\text { Discount } \\
\text { rate }\end{array}$} & \multicolumn{3}{|c|}{ All } & \multicolumn{3}{|c|}{ Crime } & \multicolumn{3}{|c|}{ Other outcomes } \\
\hline & All & Male & Female & All & Male & Female & All & Male & Female \\
\hline \multicolumn{10}{|c|}{ "High" murder cost } \\
\hline \multirow[t]{2}{*}{$0 \%$} & $\begin{array}{c}31.5 \\
(11.3)\end{array}$ & $\begin{array}{c}33.7 \\
(17.3)\end{array}$ & $\begin{array}{c}27.0 \\
(14.4)\end{array}$ & $\begin{array}{l}19.7 \\
(8.6)\end{array}$ & $\begin{array}{c}20.7 \\
(11.3)\end{array}$ & $\begin{array}{c}16.8 \\
(15.3)\end{array}$ & $\begin{array}{l}11.8 \\
(3.0)\end{array}$ & $\begin{array}{l}13.0 \\
(4.0)\end{array}$ & $\begin{array}{l}10.2 \\
(3.6)\end{array}$ \\
\hline & - & - & - & $62.7 \%$ & $61.3 \%$ & $62.1 \%$ & $37.3 \%$ & $38.7 \%$ & $37.9 \%$ \\
\hline \multirow[t]{2}{*}{$3 \%$} & $\begin{array}{l}12.2 \\
(5.3)\end{array}$ & $\begin{array}{l}12.1 \\
(8.0)\end{array}$ & $\begin{array}{l}11.6 \\
(7.1)\end{array}$ & $\begin{array}{c}8.0 \\
(4.0)\end{array}$ & $\begin{array}{c}7.2 \\
(5.1)\end{array}$ & $\begin{array}{c}8.3 \\
(7.6)\end{array}$ & $\begin{array}{c}4.2 \\
(1.1)\end{array}$ & $\begin{array}{c}4.9 \\
(1.4)\end{array}$ & $\begin{array}{c}3.3 \\
(1.4)\end{array}$ \\
\hline & - & - & - & $65.3 \%$ & $59.5 \%$ & $71.5 \%$ & $34.7 \%$ & $40.5 \%$ & $28.5 \%$ \\
\hline \multirow[t]{2}{*}{$5 \%$} & $\begin{array}{c}6.8 \\
(3.4)\end{array}$ & $\begin{array}{c}6.2 \\
(5.1)\end{array}$ & $\begin{array}{c}7.1 \\
(4.6)\end{array}$ & $\begin{array}{c}4.5 \\
(2.5)\end{array}$ & $\begin{array}{c}3.5 \\
(3.2)\end{array}$ & $\begin{array}{c}5.5 \\
(5.0)\end{array}$ & $\begin{array}{c}2.3 \\
(0.6)\end{array}$ & $\begin{array}{c}2.7 \\
(0.7)\end{array}$ & $\begin{array}{c}1.6 \\
(0.8)\end{array}$ \\
\hline & - & - & - & $66.1 \%$ & $56.4 \%$ & $76.8 \%$ & $33.9 \%$ & $43.6 \%$ & $23.2 \%$ \\
\hline \multirow[t]{2}{*}{$7 \%$} & $\begin{array}{c}3.9 \\
(2.3)\end{array}$ & $\begin{array}{c}3.2 \\
(3.4)\end{array}$ & $\begin{array}{c}4.6 \\
(3.1)\end{array}$ & $\begin{array}{c}2.6 \\
(1.7)\end{array}$ & $\begin{array}{c}1.6 \\
(2.1)\end{array}$ & $\begin{array}{c}3.7 \\
(3.4)\end{array}$ & $\begin{array}{c}1.3 \\
(0.4)\end{array}$ & $\begin{array}{c}1.6 \\
(0.4)\end{array}$ & $\begin{array}{c}0.9 \\
(0.5)\end{array}$ \\
\hline & - & - & - & $66.5 \%$ & $50.5 \%$ & $80.1 \%$ & $33.5 \%$ & $49.5 \%$ & $19.9 \%$ \\
\hline \multicolumn{10}{|c|}{ "Low" murder cost } \\
\hline \multirow[t]{2}{*}{$0 \%$} & $\begin{array}{l}19.1 \\
(5.4)\end{array}$ & $\begin{array}{c}22.8 \\
(8.3)\end{array}$ & $\begin{array}{l}12.7 \\
(3.8)\end{array}$ & $\begin{array}{c}7.3 \\
(3.2)\end{array}$ & $\begin{array}{c}9.8 \\
(5.5)\end{array}$ & $\begin{array}{c}2.5 \\
(1.5)\end{array}$ & $\begin{array}{l}11.8 \\
(3.0)\end{array}$ & $\begin{array}{l}13.0 \\
(4.0)\end{array}$ & $\begin{array}{l}10.2 \\
(3.6)\end{array}$ \\
\hline & - & - & - & $38.1 \%$ & $42.8 \%$ & $19.5 \%$ & $61.9 \%$ & $57.2 \%$ & $80.5 \%$ \\
\hline \multirow[t]{2}{*}{$3 \%$} & $\begin{array}{c}7.1 \\
(2.3)\end{array}$ & $\begin{array}{c}8.6 \\
(3.7)\end{array}$ & $\begin{array}{c}4.5 \\
(1.4)\end{array}$ & $\begin{array}{c}2.9 \\
(1.5)\end{array}$ & $\begin{array}{c}3.6 \\
(2.6)\end{array}$ & $\begin{array}{c}1.2 \\
(0.7)\end{array}$ & $\begin{array}{c}4.2 \\
(1.1)\end{array}$ & $\begin{array}{c}4.9 \\
(1.4)\end{array}$ & $\begin{array}{c}3.3 \\
(1.4)\end{array}$ \\
\hline & - & - & - & $40.2 \%$ & $42.2 \%$ & $26.5 \%$ & $59.8 \%$ & $57.8 \%$ & $73.5 \%$ \\
\hline \multirow[t]{2}{*}{$5 \%$} & $\begin{array}{c}3.9 \\
(1.5)\end{array}$ & $\begin{array}{c}4.7 \\
(2.3)\end{array}$ & $\begin{array}{c}2.4 \\
(0.8)\end{array}$ & $\begin{array}{c}1.6 \\
(1.0)\end{array}$ & $\begin{array}{c}1.9 \\
(1.7)\end{array}$ & $\begin{array}{c}0.8 \\
(0.4)\end{array}$ & $\begin{array}{c}2.3 \\
(0.6)\end{array}$ & $\begin{array}{c}2.7 \\
(0.7)\end{array}$ & $\begin{array}{c}1.6 \\
(0.8)\end{array}$ \\
\hline & - & - & - & $41.0 \%$ & $41.3 \%$ & $31.9 \%$ & $59.0 \%$ & $58.7 \%$ & $68.1 \%$ \\
\hline \multirow[t]{2}{*}{$7 \%$} & $\begin{array}{c}2.2 \\
(0.9)\end{array}$ & $\begin{array}{c}2.7 \\
(1.5)\end{array}$ & $\begin{array}{c}1.4 \\
(0.5)\end{array}$ & $\begin{array}{c}0.9 \\
(0.7)\end{array}$ & $\begin{array}{c}1.1 \\
(1.2)\end{array}$ & $\begin{array}{c}0.5 \\
(0.3)\end{array}$ & $\begin{array}{c}1.3 \\
(0.4)\end{array}$ & $\begin{array}{c}1.6 \\
(0.4)\end{array}$ & $\begin{array}{c}0.9 \\
(0.5)\end{array}$ \\
\hline & - & - & - & $41.9 \%$ & $39.1 \%$ & $36.1 \%$ & $58.1 \%$ & $60.9 \%$ & $63.9 \%$ \\
\hline
\end{tabular}

Note: The categories "Crime" and "Other outcomes" sum up to "All." Standard errors in parentheses are calculated by Monte Carlo resampling of prediction errors and bootstrapping. The percentages reported are the contributions of each component. Kernel matching is used to impute missing values in earnings before age 40, and PSID projection is used for extrapolation of later earnings. In calculating benefit-to-cost ratios, deadweight loss of taxation is assumed at $50 \%$. Lifetime net benefit streams are adjusted for corrupted randomization by being conditioned on unbalanced preprogram variables.

estimates of the overall rate of return hover in the range of $7 \%$ to $10 \%$, and they are statistically significantly different from zero in most cases.

The estimated benefit-to-cost ratios under different discount rates presented in Tables 17.1 and 17.4 generally support the rate of return analysis and are substantial for discount rates commonly used in the literature $3 \%$ to $5 \%) .{ }^{13}$ Further, as shown in Table 17.4, a considerable portion of benefits is due to crime reduction. Sensitivity analysis establishes that (a) excluding

13 Note, however, that the higher the assumed value of victim life, the higher the benefit-tocost ratio. This occurs because the discount rates in the benefit-to-cost analyses are lower than the discount rates produced by the IRR analysis. Timing of crime matters less in the benefit-cost analysis. See Heckman et al. (2010a). 
some outliers whose educational attainments are exceptionally high has only modest effects on the estimated IRRs; (b) excluding "hard-core" criminal offenders increases the estimated social IRRs obtained from the pooled sample and strengthens the precision of the estimates; and (c) accounting for local costs instead of relying on national figures increases estimated IRRs, given that criminal justice system costs for Michigan are higher than the corresponding national estimates. When we evaluate the Perry program only through age 40 to avoid uncertainty associated with extrapolation, rates of return and benefitto-cost ratios fall somewhat but still remain substantially above the historical rate of return to equity and are precisely determined (Heckman et al. 2010a). A complete analysis of the rate of return to the Perry program under various assumptions can be found in our source paper.

\section{CONCLUSION}

This chapter summarizes the main results from our previous work on estimating the rate of return to the Perry Preschool Program (Heckman et al. 2010a). We account for locally determined costs, missing data, the deadweight costs of taxation, and the value of nonmarket benefits and costs. Our analysis improves on previous estimates by accounting for compromise in the randomization protocol, by developing standard errors for the estimates, and by exploring the sensitivity of estimates to alternative assumptions about missing data and the value of nonmarket benefits. Our estimates are also robust to a variety of alternative assumptions about interpolation, extrapolation, and deadweight losses. In most cases, they are statistically significantly different from zero. This is true for both males and females. In general, the estimated rates of return are above the historical return to equity of about $5.8 \%$ but are well below previous estimates reported in the literature. Our benefit-to-cost ratio estimates support the rate of return analysis. Benefits from improvements in health and the well-being of future generations are not estimated due to data limitations. Our analysis likely provides a lower bound on the true rate of return to the Perry Preschool Program.

\section{REFERENCES}

Anderson, D. A. (1999). The aggregate burden of crime. Journal of Law and Economics, 42(2), 611-642.

Anderson, M. (2008). Multiple inference and gender differences in the effects of early intervention: A reevaluation of the Abecedarian, Perry Preschool, and Early Training Projects. Journal of the American Statistical Association, 103(484), 1481-1495.

Barnett, W. S. (1996). Lives in the balance: Age 27 benefit-cost analysis of the High/Scope Perry Preschool Program. Ypsilanti, MI: High/Scope Press.

Belfield, C. R., Nores, M., Barnett, W. S., \& Schweinhart, L. (2006). The HighScope Perry Preschool Program: Cost-benefit analysis using data from the age- 40 followup. Journal of Human Resources, 41(1), 162-190. 
Cohen, M. A. (2005). The costs of crime and justice. New York: Routledge.

Congressional Budget Office (2007). Historical effective federal tax rates: 1979 to 2005.

[Data tables]. Available from Congressional Budget Office Website: http://www.cbo. gov/ftpdocs/88xx/doc8885/12-11-HistoricalTaxRates.pdf.

DeLong, J. B., \& Magin, K. (2009). The U.S. equity return premium: Past, present and future. Journal of Economic Perspectives, 23(1), 193-208.

Hanushek, E., \& Lindseth, A. A. (2009). Schoolhouses, courthouses, and statehouses: Solving the funding-achievement puzzle in America's public schools. Princeton, NJ: Princeton University Press.

Hause, J. C. (1980). The fine structure of earnings and the on-the-job training hypothesis. Econometrica, 48(4), 1013-1029.

Heckman, J. J., Moon, S. H., Pinto, R., Savelyev, P. A., \& Yavitz, A. Q. (2010a). The rate of return to the HighScope Perry Preschool Program. Journal of Public Economics, 94(1): 114-128.

Heckman, J. J., Moon, S. H., Pinto, R., Savelyev, P. A., \& Yavitz, A. Q. (2010b). A reanalysis of the HighScope Perry Preschool Program. In press, Quantitative Economics.

Herrnstein, R. J., \& Murray, C. A. (1994). The bell curve: Intelligence and class structure in American life. New York: Free Press.

Moffitt, R. A. (2003). The negative income tax and the evolution of U.S. welfare policy. Journal of Economic Perspectives, 17(3), 119-140.

National Center for Health Statistics. (2004). National Vital Statistics Report, 53(5). Washington, DC: U.S. Department of Health and Human Services.

Rolnick, A., \& Grunewald, R. (2003, March). Early childhood development: Economic development with a high public return. Fedgazette, Federal Reserve Bank of Minneapolis.

Schweinhart, L. J., Montie, J., Xiang, Z., Barnett, W. S., Belfield, C. R., \& Nores, M. (2005). Lifetime effects: The HighScope Perry Preschool Study through age 40. Ypsilanti, MI: High/Scope Press.

Tsang, M. C. (1997). The cost of vocational training. International Journal of Manpower, $18(1 / 2), 63-89$. 